\title{
ANALISIS KOORDINASI ISOLASI DI GARDU INDUK KUTA TERHADAP TEGANGAN LEBIH AKIBAT SAMBARAN PETIR PADA SALURAN TRANSMISI $150 \mathrm{KV}$
}

\author{
Analysis Of Insulation Coordination In Kuta Substation To Over Voltage Due To \\ Lightning Stricke at 150 kV High Voltage Transmission System
}

\author{
Elan Criyanto ${ }^{1}$, Supriyatna ${ }^{1}$, Agung Budi Muljono'
}

${ }^{1}$ JurusanTeknik Elektro ,FakultasTeknik Universitas Mataram, Nusa Tenggara Barat

'Email: elancriyanto@yahoo.com, supriyatna@unram.ac.id, agungbm@unram.ac.id

\begin{abstract}
ABSTRAK
Sambaran petir pada saluran transmisi $150 \mathrm{kV}$ dapat menimbulkan tegangan lebih yang akan membahayakan peralatan jika tegangan tersebut melampaui tingkat isolasi dasar peralatan (TID). Metode untuk mengetahui nilai lightning performance digunakan teori gelombang berjalan dan elektrogeometris. Metode pantulan berulang digunakan untuk menentukan jarak maksimum antara arrester dengan peralatan yang dilindunginya. Berdasarkan hasil penghitungan diperoleh jumlah gangguan petir pada saluran transmisi $150 \mathrm{kV}$ Sengkol-Kuta yaitu 1,2984 gangguan per $100 \mathrm{~km}$ pertahun dengan kualifikasi "Pentanahan bagus; perisai cukup" sehingga tidak perlu dilakukan perbaikan. Koordinasi isolasi di gardu induk Kuta terhadap tegangan lebih akibat sambaran petir pada saluran transmisi $150 \mathrm{kV}$ dikatakan baik karena: Dari hasil perhitungan didapatkan nilai arus pelepasan arrester sebesar 3,9180 kA. Sedangkan arus pelepasan nominal arrester sebesar $10 \mathrm{kA}$. Hal ini berarti bahwa arus pelepasan arrester lebih kecil 6,0820 kA dari arus pelepasan nominal. Jarak maksimum pemasangan arrester dan transformator sebesar 57 meter. Sedangkan jarak pemasangan arrester dan transformator yang ada dilapangan sebesar 48 meter. Hal ini berarti bahwa jarak pemasangan arrester dan transformator yang ada dilapangan lebih kecil 9 meter dari jarak maksimum arrester dan transformator dari hasil perhitungan. Tegangan akhir yang sampai di transformator sebesar 588,2783 kV. Sedangkan Tingkat Isolasi Dasar (TID) transformator yang digunakan sebesar $650 \mathrm{kV}$. Hal ini berarti bahwa tegangan tertinggi pada transformator lebih kecil $61,7217 \mathrm{kV}$ dari Tingkat Isolasi Dasar (TID) transformator yang digunakan.
\end{abstract}

Kata Kunci: Petir, Kinerja pengamanan petir, Koordinasi isolasi

\begin{abstract}
Lightning strikes on transmission lines can cause over voltage which would endanger the equipment if the voltage is exceed the equipment basic isolation level (BIL). Methods to determine the value of lightning performance used the theory of traveling waves and electrogeometric. The method repeated reflection is used to determine the maximum distance between the arrester and the equipment it protects. Based on the calculation results obtained the number of lightning disturbance on the transmission line $150 \mathrm{kV}$ Sengkol - Kuta is 1,2984 disturbance per $100 \mathrm{~km}$ per year with qualification "Good grounding; fair shielding "so no repair needed. The coordination of the isolation in the Kuta main substation against the over voltage caused by the lightning strike on the $150 \mathrm{kV}$ transmission line is said to be good because: From the calculation results obtained the release value of the arrester of 3,9180 kA. While the nominal discharge current of $10 \mathrm{kA}$ arresters. This means that the release flow of the arrester is 6,0820 kA smaller than the nominal discharge current. The maximum distance of installation of arresters and transformers is 57 meters. While the installation distance of existing arrester and transformer in the field of 48 meters. This means that the installation distance of the existing arrester and transformer is smaller than 9 meters from the maximum distance of the arrester and the transformer from the calculation. The final voltage reaching the transformer is 588,2783 $\mathrm{kV}$. While the Basic Isolation Level (BIL) of the transformer used is $650 \mathrm{kV}$. This means that the highest voltage on the transformer is smaller $61,7171 \mathrm{kV}$ from the Basic Isolation Level (BIL) of the transformer used.
\end{abstract}

Keywords: Lightning, Lightning performance, insulation coordination 


\section{PENDAHULUAN}

Sambaran petir pada saluran transmisi dapat menimbulkan tegangan lebih transien pada peralatan yang akan membahayakan bila tegangan tersebut melampaui tingkat isolasi dasar peralatan. Sehingga untuk menanggulangi permasalahan tersebut diterapkan konsep koordinasi isolasi pada sistem. Adanya koordinasi isolasi pada saluran udara tersebut untuk menghindari terjadinya kerusakan pada peralatan.

Gardu Induk sebagai penyalur energi listrik ke konsumen perlu dilindungi dari gangguan yang disebabkan oleh petir. Perlindungan peralatan pada gardu induk biasanya menggunakan arrester yang dapat membatasi besar tegangan surja di bawah tingkat isolasi dasar peralatan. Sehingga konsep perlindungan terhadap peralatan dalam hal ini koordinasi isolasi dapat tercapai secara optimal.

Indonesia yang terletak didaerah tropis sehingga membuat Isokeraunic Level (IKL) sangat tinggi yaitu lebih dari 200 sambaran/ $\mathrm{km}^{2}$ /tahun. Berdasarkan data BMKG Stasiun Meteorologi BIL, jumlah hari guruh di Lombok Tengah pada tahun 2016 adalah 121 hari pertahun. Saluran transmisi yang menuju ke Gardu Induk Kuta melalui daerah perbukitan sehingga potensi terkena sambaran petir cukup tinggi. Gardu Induk Kuta termasuk gardu induk yang baru beroperasi sehingga diperlukan penelitian agar kedepannya dapat mencegah terjadinya gangguan pada peralatan gardu dan terlindung efektif dari gangguan tegangan lebih. Gangguangangguan tegangan lebih merupakan faktor yang mempengaruhi keandalan dan kontinyuitas pelayanan daya listrik. Selain itu, Gardu Induk Kuta melayani daerah pariwisata sehingga pelayanan daya listrik harus bagus dan terhindar dari gangguan.

Berdasarkan penjelasan di atas maka pada penelitian ini akan dibahas "analisis koordinasi isolasi di gardu induk kuta terhadap tegangan lebih akibat sambaran petir pada saluran transmisi $150 \mathrm{kV}$ ".

\section{Gangguan Petir Pada Saluran Udara Tegangan Tinggi.}

Tujuan menentukan jumlah gangguan petir pada saluran transmisi adalah untuk mengetahui sifat kerja saluran transmisi terhadap petir, yang biasanya dinyatakan dalam satuan gangguan $/ 100 \mathrm{~km} / \mathrm{tahun}$. Gangguan petir akibat sambaran langsung terbagi atas dua mekanisme yaitu gangguan petir pada kawat fasa atau kegagalan perlindungan dan gangguan petir pada kawat tanah (Hutauruk, 1991).

Rumus jumlah gangguan itu dapat dinyatakan sebagai berikut:

$$
N_{0}=N_{S F}+N_{\mathrm{t}}+N_{q}+N_{m}
$$

Keterangan:

$$
\begin{aligned}
& N_{0}=\text { Jumlah gangguan petir pada } \\
& \text { saluran transmisi. } \\
& N_{S F} \quad=\text { Jumlah kegagalan perlindungan. } \\
& N_{t} \quad=\text { Jumlah gangguan petir pada } \\
& \text { menara transmisi. } \\
& N_{q} \quad=\text { Jumlah gangguan petir pada } \\
& \text { seperempat jarak dari menara. } \\
& N_{m} \quad=\text { Jumlah gangguan petir pada } \\
& \text { setengah jarak dari menara. }
\end{aligned}
$$

\section{Kegagalan Perisaian.}

Bila sambaran petir mendekat pada jarak $\mathrm{S}$ dari saluran dan bumi, sambaran petir itu dipengaruhi oleh benda apa saja yang berada di bawah dan melompati jarak $S$ untuk mengadakan kontak dengan benda itu. Jarak $S$ disebut jarak sambaran, dan inilah konsep dari teori elektro-geometris itu (Hutauruk, 1991).

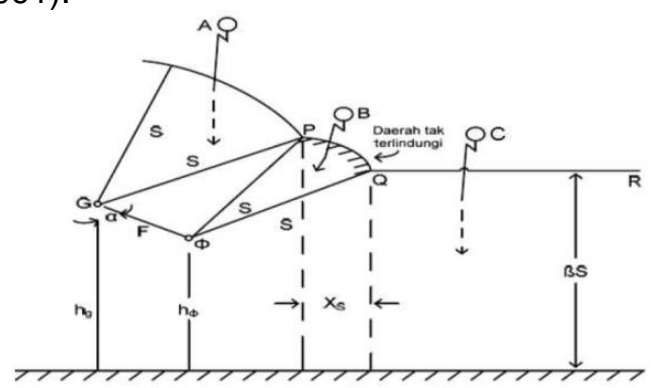

Gambar 1. Perisaian tidak sempurna, Xs daerah tidak terlindung (Hutauruk, 1991).

Probabilitas arus melebihi arus tertentu (I) adalah:

$$
P_{I}=e^{-I / I_{A 4}}
$$

Jika kedua kawat fasa terletak simetris terhadap kawat tanah maka jumlah kegagalan perisaian menjadi :

$$
\mathrm{N}_{\mathrm{SF}}=0,015 I K L X_{S}\left(P_{\text {min }}-P_{\text {maks }}\right)
$$

\section{Gangguan Petir pada Menara.}

Untuk menghitung gangguan petir pada menara, yaitu gangguan karena lompatan api balik(back flashover), digunakan teori gelombang berjalan.

Dengan anggapan bahwa jumlah sambaran pada menara adalah $60 \%$ dari seluruh sambaran, maka jumlah gangguan pada menara adalah: (Hutauruk, 1991)

$$
\mathrm{N}_{\mathrm{t}} \quad=\eta \times 0,6 \times \mathrm{N}_{\mathrm{L}} \times \mathrm{P}_{\mathrm{FL}}
$$




\section{Gangguan Petir pada Seperempat Jarak dan Setengah Jarak Dari Menara}

Untuk memperoleh gangguan pada seperempat jarak dari menara, $N_{q}$, dan gangguan pada setengah jarak dari menara, $N_{m}$ ditunjukan pada persamaan (5) dan (6) (Hutauruk, 1991).

$$
\begin{aligned}
& N_{q}=0,3 \times \text { probabilitas } \times \frac{I K L}{30} \times \frac{1}{1,61} \\
& N_{m}=0,1 \times \text { probabilitas } \times \frac{I K L}{30} \times \frac{1}{1,61}
\end{aligned}
$$

Koordinasi Isolasi adalah 'pemilihan kekuatan isolasi'.Tujuan koordinasi isolasi adalah untuk melindungi peralatan dan penghematan (ekonomis). Dengan kedua tujuan tersebut suatu sistem tenaga listrik akan memiliki daya isolasi yang dapat diatur sedemikian rupa, kualitas pelayanan menjadi semakin baik, dan biaya yang dikeluarkan minimum (Zoro, 2011).

Arrester berfungsi untuk melindungi peralatan sistem tenaga listrik dengan cara membatasi surja tegangan lebih yang datang dan mengalirkannya ke tanah.

Bagian penting dari sebuah arester yaitu:

1. Elektroda

Pada arrester terdapat dua elektroda yaitu elektroda atas yang dihubungkan dengan bagian yang bertegangan dan elektroda bawah yang dihubungkan dengan tanah.

2. Spark gap (sela percik)

Apabila terjadi tegangan lebih yang diakibatkan oleh sambaran petir atau surja hubung pada arester yang terpasang, maka pada sela percikan (spark gap) akan terjadi loncatan busur api dan ditiup keluar oleh tekanan gas yang di timbulkan oleh tabung fiber yang terbakar.

3. Tahanan katup/kran

Tahanan yang dipergunakan dalam arrester ini adalah suatu jenis material yang sifat tahanannya dapat berubah bila mendapatkan perubahan tegangan.

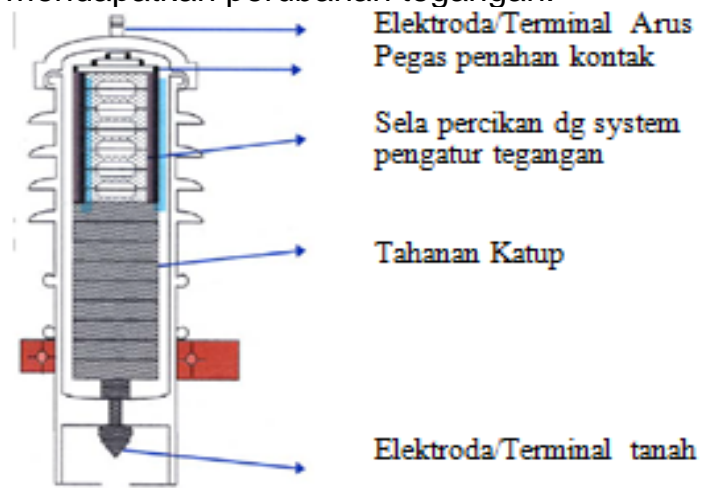

Gambar 2. Bagian-bagian lightning arrester (Team O \& M, 1981)
Tegangan pengenal arrester adalah tegangan dimana arreaster masih dapat bekerja sesuai dengan karakteristiknya. Tegangan pengenal arrester dapat dihitung menggunakan persamaan (7)yaitu:(Zoro, 2011)

$$
E_{y} \quad=\alpha \times \beta \times U_{m}
$$

Keterangan:

$E_{\%} \quad=$ Tegangan pengenal $(\mathrm{kV})$.

$\alpha \quad=$ Koefisien Pentanahan.

$\beta=$ Toleransi fluktansi tegangan

$U_{m} \quad=$ Tegangan nominal system $(\mathrm{kV})$.

Persamaan untuk menentukan arus pelepasan yang mengalir melalui arrester yaitu: (Zorro, 2011)

$$
I_{\alpha} \quad=\frac{2 U_{\alpha}-U_{匹}}{Z_{\phi}}
$$

Keterangan :

$$
\begin{array}{ll}
I_{\alpha} & =\text { Arus pelepasan arrester }(\mathrm{kA}) \\
U_{\mathbb{d}} & =\text { Tegangan gelombang datang }(\mathrm{kV}) \\
U_{\alpha} & =\text { Tegangan sisa }(\mathrm{kV}) \\
Z_{\varnothing} & =\text { Impedansi Surja Saluran }(\Omega)
\end{array}
$$

\section{Jarak Arester dan Transformator}

Perlindungan yang baik diperoleh jika arrester ditempatkan sedekat mungkin dengan peralatan yang dilindungi. Tetapi, dalam kenyataannya arrester harus ditempatkan dengan jarak tertentu untuk memperoleh kawasan perlindungan yang lebih baik (Zoro, 2011).

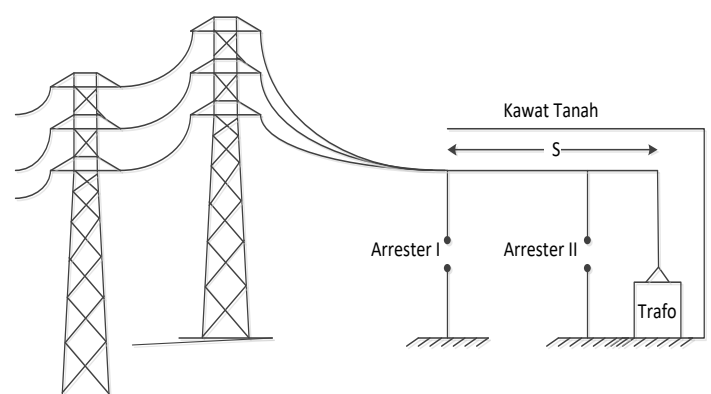

Gambar 3.Jarak Arrester dengan peralatan yang dilindungi (Tansformator).

Jarak maksimum antara arrester dengan trafo (S) dihitung berdasarkan persamaan (9) yaitu: (Zoro, 2011)

$$
s=\left(E_{p}-E_{a}\right) \times \frac{v}{2 A}
$$

Keterangan:

$E_{p}=$ Tegangan terminal transformator $(k V)$

$\mathrm{E}_{\mathrm{a}}=$ Tegangan percik Arrester $(\mathrm{kV})$

$\mathrm{A}=$ Kecuraman Muka Gelombang $(\mathrm{kV} / \mu \mathrm{s})$

$v=$ Kecepatan gelombang berjalan $(\mathrm{m} / \mathrm{s})$ 


\section{METODE PENELITIAN}

Penelitian ini dilakukan untuk mengetahui jumlah gangguan petir pada saluran transmisi dan mengetahui bagaimana koordinasi isolasi di gardu induk Kuta terhadap tegangan lebih akibat sambaran petir pada saluran transmisi $150 \mathrm{kV}$. Penelitian ini dimulai dengan menghitung gangguan petir pada kawat fasa, menghitung gangguan petir pada kawat tanah, menghitung arus pelepasan arrester, menghitung jarak pemasangan antara arrester dengan transformator, dan menghitung nilai tegangan lebih pada transformator, kemudian melakukan analisis hasil perhitungan.

\section{Data penelitian.}

Penelitian ini menggunakan data-data dari PT. PLN (Persero) APDP Mataram dan Badan Meteorologi Klimatologi dan Geofisika (BMKG) Stasiun Meteorologi BIL. Meliputi data hari guruh (IKL), data saluran transmisi 150 kV, Single Line Diagram, dan data peralatan yang terdapat di Gardu Induk Kuta. Alur penelitian ini dapat dilihat pada Gambar 4

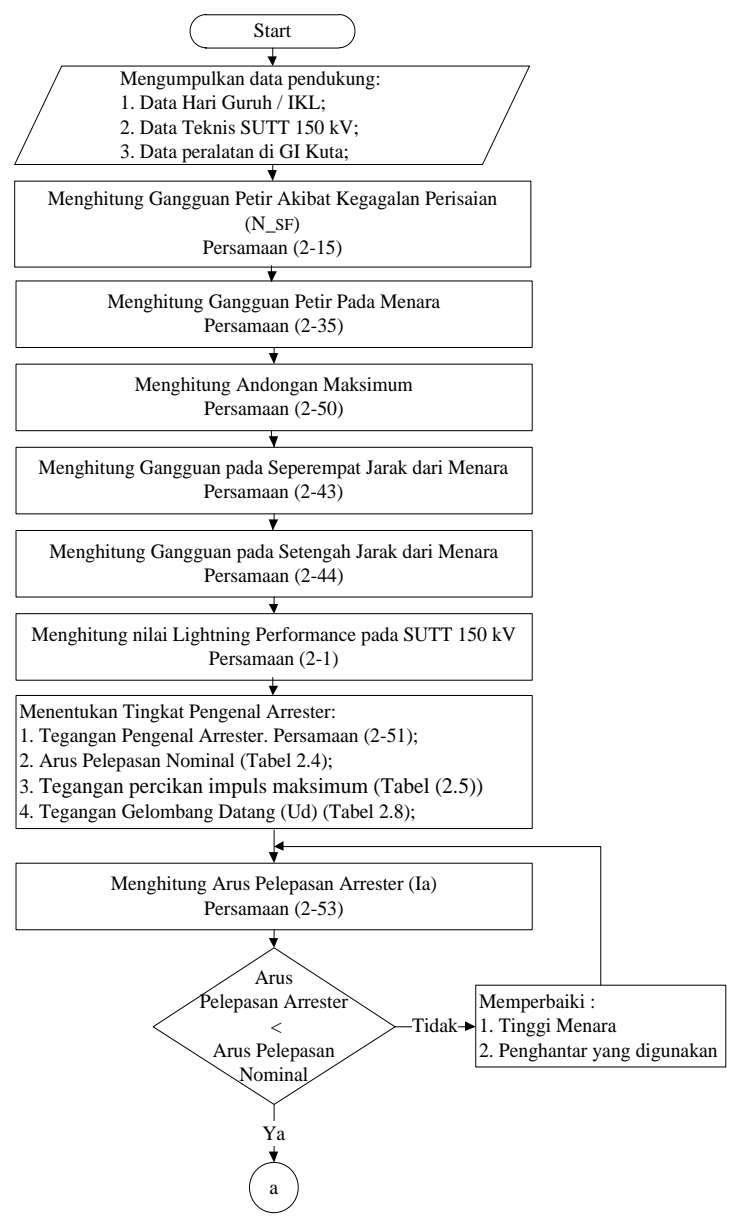

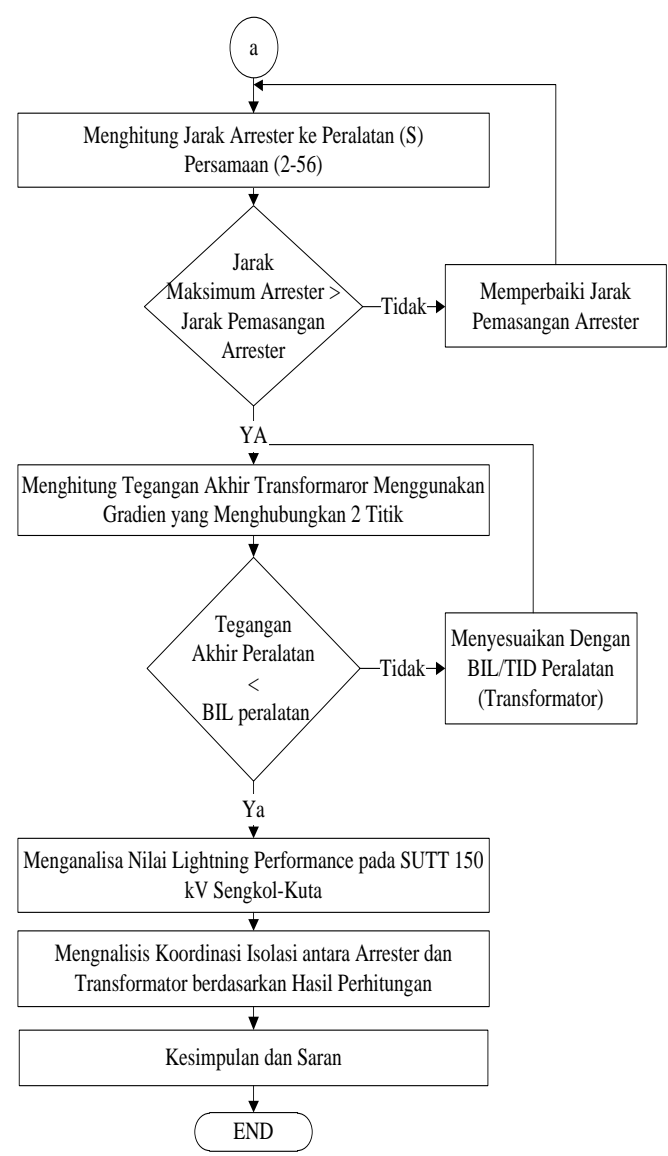

Gambar 4. Diagram alir penelitian.

HASIL DAN PEMBAHASAN

Data Teknis Saluran Udara Tegangan Tinggi (SUTT) 150 kV.

Sistem Transmisi 150 kV Sengkol-Kuta merupakan bagian dari Sistem Interkoneksi Lombok. Transmisi ini berjarak $12,00 \mathrm{~km}$ dan ditopang oleh menara sebanyak 39 unit. Transmisi ini menggunakan saluran ganda.

Kawat Tanah

Material : Galvanized Steel Wire

Jumlah : 2 buah

Diameter : 9,6 mm

Konduktor

Material : ACSR $240 \mathrm{~mm} 2$

Diameter: $21,9 \mathrm{~mm}$

Berat konduktor : $0,987 \mathrm{~kg} / \mathrm{m}$

Tegangan mendatar : $8640 \mathrm{~kg}$

Isolator

Material : Glass

Panjang isolator : $146 \mathrm{~mm}$

Jumlah : 12 buah

Menara 


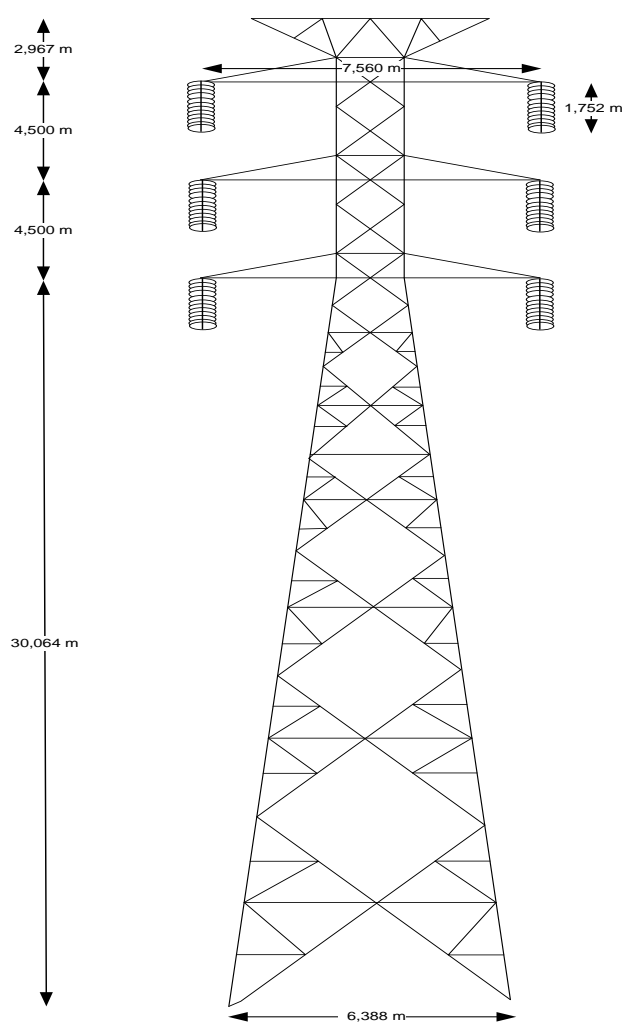

Gambar 5. Konfigurasi SUTT 150 kV.

\section{Perhitungan Kegagalan Perisaian.}

Langkah-langkah perhitungan kegagalan perisaian dapat dilihat pada Tabel 1 . Bersadarkan Tabel 1, diperoleh jumlah gangguan petir karena kegagalan perisaian sebesar 0,3466 gangguan/100 km/tahun.

\section{Perhitungan Gangguan Petir pada Menara} Transmisi.

Langkah-langkah perhitungan gangguan petir pada menara transmisi dapat dilihat pada Tabel 2.

* Tegangan pada isolator untuk arus petir 100 kA dan waktu muka gelombang petir 1,0 $\mu$ det.

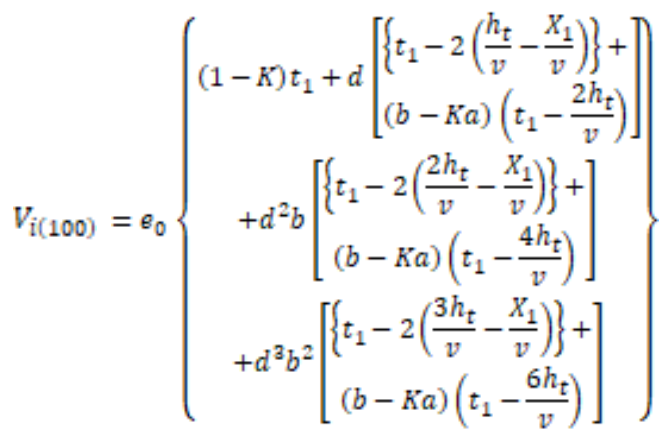

Tabel 1. Perhitungan kegagalan perisaian

\begin{tabular}{|c|c|c|}
\hline No & Rumus & Hasil \\
\hline 1 & $Y_{g}=\mathrm{h}_{\mathrm{t}}-\frac{2}{3} \times(D)$ & 41,2847 \\
\hline 2 & $Y_{\phi}=\mathrm{h}_{a f}-\frac{2}{3} \times(D)$ & 32,0657 \\
\hline 3 & $V_{5076}=\left(k_{1}+\frac{k_{2}}{t^{0,75}}\right) \times 10^{3}$ & $1.025,273$ \\
\hline 4 & $R_{\phi} \ln \left(\frac{2 Y_{\phi}}{R_{\phi}}\right)=\frac{V_{5096}}{E_{0}}$ & 0,1068 \\
\hline 5 & $z_{\emptyset}=60 \sqrt{\ln \frac{2 \times Y_{\phi}}{r_{f}} \ln \frac{2 \times Y_{\phi}}{R_{\varnothing}}}$ & 446,985 \\
\hline 6 & $I_{\min }=\frac{2 \times V_{5096}}{Z_{\emptyset}}$ & 4,5875 \\
\hline 7 & $S_{\min }=8 I_{\min } 0,65$ & 21,5335 \\
\hline No & Rumus & Hasil \\
\hline 8 & $X_{S}=\mathrm{S}\left(1+\sin \left(\alpha_{S}-\omega\right)\right)$ & 1.0814 \\
\hline 9 & $S_{\text {maks }}=Y_{0}\left(\frac{-B_{S}-\sqrt{B_{S}{ }^{2}+}}{A_{S}}\right.$ & ig. 8057 \\
\hline 10 & $I_{\text {mahs }}=\sqrt[0_{i, f 5}]{\frac{S_{\text {maks }}}{8}}$ & 12,2648 \\
\hline 11 & $P_{\min }=e^{-\frac{I_{\min }}{94}}$ & 0,8738 \\
\hline 12 & $P_{\text {mahs }}=e^{-\frac{I_{\text {makn }}}{34}}$ & 0,6972 \\
\hline 13 & $\begin{array}{c}\mathrm{N}_{\mathrm{SF}}=0,015 \times I K L \times X_{S} \times \\
\left(P_{\min }-P_{\text {mahs }}\right) \\
\text { (gangguan } / 100 \mathrm{~km} / \text { tahun) }\end{array}$ & 0,346 \\
\hline
\end{tabular}

Berdasarkan Tabel 2, diperoleh jumlah gangguan petir pada menara transmisi sebesar 0,58243 gangguan $/ 100 \mathrm{~km} /$ tahun.

Perhitungan Gangguan Petir pada arak dari Menara.

Data diketahui:

$h_{\mathrm{t}}=42,031 \mathrm{~m}$

$h_{\mathrm{t}}^{v}=28,312 \mathrm{~m}$

$d_{0}=3,2562 \mathrm{~m}$

$d_{0}^{s}=3,2562 \mathrm{~m}$

$\mathrm{p}=0,938 \mathrm{~m}$

Span $=280 \mathrm{~m}$

$\mathrm{IKL}=121$ 
Tabel 2. Perhitungan gangguan petir pada menara transmisi

\begin{tabular}{|c|c|c|c|}
\hline $\begin{array}{l}N \\
0\end{array}$ & & Rumus & Hasil \\
\hline \multirow{2}{*}{1} & $Z_{g}$ & $=60 \ln \frac{2 \times h_{t}}{\sqrt{a_{12} \times r_{g}}}$ & 373,9378 \\
\hline & $K_{C}$ & $=\frac{Z_{C 1}+Z_{C 2}}{Z_{22}+Z_{12}}$ & 0,2637 \\
\hline 2 & $Z_{t}$ & $=30 \ln \left[\frac{2\left(h_{t}^{2}+r_{m}{ }^{2}\right)}{r_{m}{ }^{2}}\right]$ & 175,5952 \\
\hline \multirow[t]{2}{*}{3} & $a$ & $=\frac{2 \times Z_{g}}{Z_{g}+2 Z_{t}}$ & 1,0314 \\
\hline & $b$ & $=a-1$ & 0,0314 \\
\hline 4 & $e_{p}$ & $=\frac{Z_{g} Z_{t}}{Z_{g}+2 Z_{t}} \times \frac{I_{0}}{t_{1}}$ & 90,5518 \\
\hline 5 & $d$ & $=\frac{R_{k}-Z_{t}}{R_{k}+Z_{t}}$ & $-0,9775$ \\
\hline 6 & & $V_{\mathrm{i}\{100\}}$ & $1.133,25$ \\
\hline 7 & $A_{B L}$ & $=0,1\left(\mathrm{~b}+4 Y_{g}^{1,09}\right)$ & 23,6502 \\
\hline 8 & $\mathrm{~N}_{\mathrm{L}}$ & $=0,15 \times I K L \times A_{B L}$ & $\begin{array}{c}429,251 \\
1 \\
\end{array}$ \\
\hline 9 & $\mathrm{~N}_{\mathrm{t}}$ & $\begin{array}{l}=0,6 \times \eta \times \mathrm{N}_{\mathrm{L}} \times \mathrm{P}_{\mathrm{FL}} \\
\text { (gangguan } / 100 \mathrm{~km} / \mathrm{tal}\end{array}$ & $\begin{array}{l}0,5473 \\
\text { un) }\end{array}$ \\
\hline
\end{tabular}

Perhitungan Jumlah Gangguan Petir pada Seperempat Jarak dari Menara $\left(N_{q}\right)$.

$$
\begin{gathered}
b_{q}=\left(h_{\mathrm{t}}-\frac{d_{0}}{4}\right)-\left(h_{\mathrm{t}}{ }^{\circ}-\frac{d_{0}{ }^{\mathrm{f}}}{4}\right)=13,7190 \mathrm{~m} \\
d_{q}=\sqrt{b_{q}{ }^{2}+\rho^{2}}=13,7510 \mathrm{~m}=45,1144 \mathrm{ft} \\
N_{q} \quad=0,3 \times \text { probabilitas } \times \frac{I K L}{30} \times \frac{1}{1,61} \\
=0,3006 \text { gangguan } / 100 \mathrm{~km} / \mathrm{tahun}
\end{gathered}
$$

Perhitungan Jumlah Gangguan Petir pada Setengah Jarak dari Menara $\left(N_{m}\right)$.

$$
\begin{aligned}
& b_{m}=\left(h_{\mathrm{t}}-d_{0}\right)-\left(h_{\mathrm{t}}{ }^{f}-d_{0}{ }^{f}\right)=13,7190 \mathrm{~m} \\
& d_{m}=\sqrt{b_{m}{ }^{2}+\rho^{2}}=13,7510 \mathrm{~m}=45,1144 \mathrm{ft} \\
& N_{m}=0,1 \times \text { probabilitas } \times \frac{I K L}{30} \times \frac{1}{1,61} \\
& =0,1002 \text { gangguan } / 100 \mathrm{~km} / \text { tahun }
\end{aligned}
$$

Perhitungan Nilai Lightning Performance pada SUTT.

Untuk menghitung nilai lightning performance pada SUTT digunakan Persamaan (1).

$$
\begin{aligned}
\mathrm{LP} & =\mathrm{N}_{\mathrm{SF}}+\mathrm{N}_{\mathrm{t}}+\mathrm{N}_{\mathrm{q}}+\mathrm{N}_{\mathrm{m}} \\
& =0,3432+0,5473+0,3006+0,1002
\end{aligned}
$$$$
=1,2948 \text { gangguan per } 100 \mathrm{~km} \text { per tahun }
$$

Jadi nilai lightning performance yang diperoleh dari perhitungan untuk SUTT 150kV Sengkol-Kuta adalah 1,2948 gangguan/ 100 $\mathrm{km} /$ tahun. Sehingga penilaian lightning performance saluran transmisi $150 \mathrm{kV}$ Sengkol-Kuta menurut Standar Trip-out memiliki kualifikasi "Pentanahan bagus; perisai yang cukup", sehingga tidak perlu dilakukan perbaikan.

Menghitung tegangan pengenal arrester. Tegangan pengenal arrester dihitung dengan menggunakan persamaan (7) yaitu:

$$
\begin{aligned}
E_{\gamma} \quad & =\alpha \times \beta \times U_{m} \\
& =(0.8) \times(110 \%) \times(150) \\
& =132 \mathrm{kV}
\end{aligned}
$$

Penentuan Tingkat Keamanan Arrester. Penentuan tingkat keamanan arrester dapat ditentukan dengan cara mengetahui nilai arus pelepasan arrester pada saat saluran terkena sambaran petir. Arus pelepasan arrester dihitung menggunakan persamaan (8) yaitu:

$$
\begin{aligned}
I_{\alpha} & =\frac{2 U_{d}-E_{\alpha}}{Z_{S}} \\
& =\frac{(2 \times 1.105)-460}{446,9858} \\
& =3,9151 \mathrm{kA}
\end{aligned}
$$

Perhitungan jarak maksimum antara arrester dan transformator.

Jarak maksimum antara arrester dengan trafo (S) dihitung berdasarkan persamaan (9) yaitu:

$$
\begin{aligned}
S \quad & =\left(E_{p}-E_{a}\right) \cdot \frac{V}{2 A} \\
& =(650-460) \cdot \frac{300}{2 \times 500} \\
& =57 \mathrm{~m}
\end{aligned}
$$

Menghitung tegangan pada arrester dan waktu percik arrester.

Data dilapangan didapatkan jarak pemasangan antara arrester ke transformator sebesar $48 \mathrm{~m}$ untuk lightning arrester 1 dan $3,5 \mathrm{~m}$ untuk lightning arrester 2. Kecepatan 
gelombang $300 \mathrm{~m} / \mu \mathrm{s}$, sehingga rentang waktu yang digunakan adalah:

$$
t=\frac{s}{v}=\frac{48}{300}=0,16 \mu s
$$

Proses pantulan gelombang surja dapat digambarkan dalam sebuah diagram tangga pada gambar 6 .

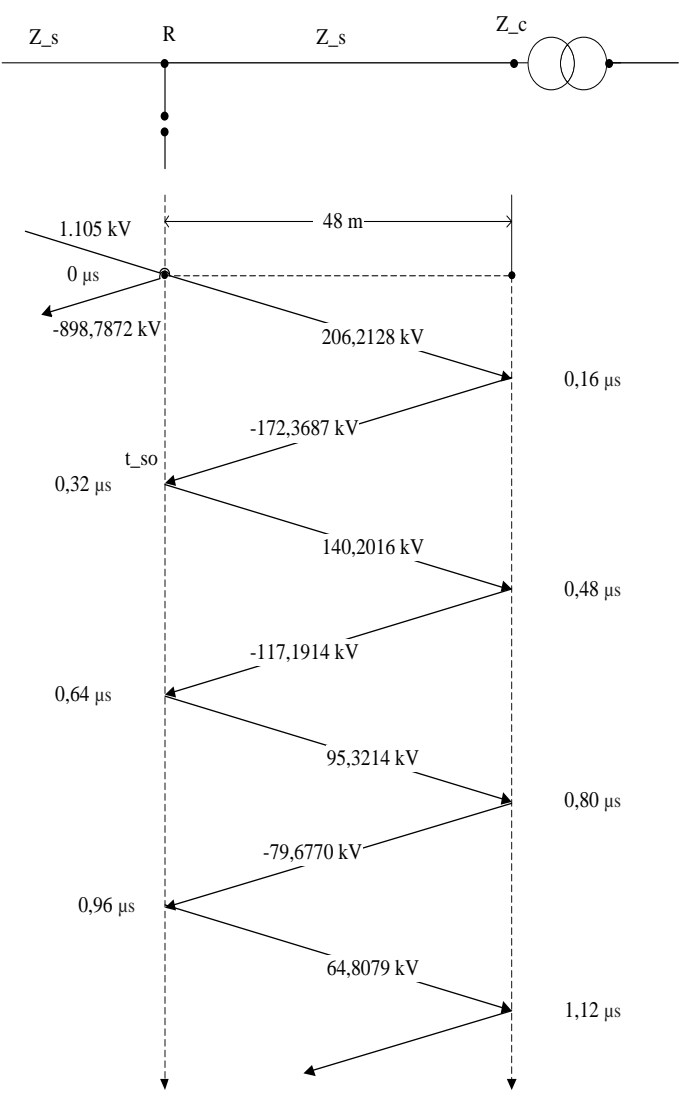

Gambar 6. Diagram tangga.

\section{Menghitung tegangan pada arrester.}

$$
\begin{aligned}
& \text { Untuk } \mathrm{t}=0,00 \mu \mathrm{s} \\
& \mathrm{E}_{\text {0 arrester }}=0,0000 \mathrm{kV} \\
& \text { Untuk } \mathrm{t}=0,16 \mu \mathrm{s} \\
& \mathrm{E}_{1 \text { arrester }}=\mathrm{E}_{0 \text { arrester }}+\mathrm{e}_{0 \text { pantul }}+\mathrm{e}_{1 \text { pantul }} \\
& =0,0000+0,0000+206,2128 \\
& =206,2128 \mathrm{kV} \\
& \text { Untuk t }=0,32 \mu s \\
& \mathrm{E}_{2 \text { arrester }}=\mathrm{E}_{1 \text { arrester }}+\mathrm{e}_{1 \text { pantul }}+\mathrm{e}_{2 \text { pantul }} \\
& =206,2128+206,2128+172,3687 \\
& =584,7944 \mathrm{kV} \\
& \text { Untuk } \mathrm{t}=0,48 \mu \mathrm{s} \\
& \mathrm{E}_{\text {a arrester }}=\mathrm{E}_{2 \text { arrester }}+\mathrm{e}_{2 \text { pantul }}+\mathrm{e}_{\mathrm{j} \text { pantul }} \\
& =584,7944+172,3687+140,2016 \\
& =897,3648 \mathrm{kV} \\
& \text { Untuk t }=0,64 \mu \mathrm{s} \\
& \mathrm{E}_{4 \text { arrester }}=\mathrm{E}_{\text {a arrester }}+\mathrm{e}_{\mathrm{a} \text { pantul }}+\mathrm{e}_{4 \text { pantul }}
\end{aligned}
$$

$$
\begin{aligned}
& =897,3648+140,2016+117,1914 \\
& =1,154,7578 \mathrm{kV}
\end{aligned}
$$

Untuk $\mathrm{t}=0,80 \mu \mathrm{s}$

$$
\begin{aligned}
\mathrm{E}_{5 \text { arrester }} & \mathrm{E}_{4 \text { arrester }}+\mathrm{e}_{4 \text { pantul }}+\mathrm{e}_{5 \text { pantul }} \\
& =1.154,7578+117,1914+95,3214 \\
& =1.367,3214 \mathrm{kV}
\end{aligned}
$$

Tegangan pada arrester dapat dicari untuk rentang waktu selanjutnya dan hasilnya dapat dilihat pada tabel 3 .

Tabel 3. Tegangan pada arrester.

\begin{tabular}{|c|c|c|}
\hline No & $\begin{array}{c}\text { Waktu } \\
(\mu \mathrm{s})\end{array}$ & $\begin{array}{c}\text { Tegangan pada arrester } \\
(\mathrm{kV})\end{array}$ \\
\hline 1 & 0,00 & 0,0000 \\
\hline 2 & 0,16 & 206,2128 \\
\hline 3 & 0,32 & 584,7944 \\
\hline 4 & 0,48 & 897,3648 \\
\hline 5 & 0,64 & $1.154,7578$ \\
\hline 6 & 0,80 & $1.367,3214$ \\
\hline 7 & 0,96 & $1.542,3198$ \\
\hline
\end{tabular}

Kemudian menghitung waktu percik arrester yaitu:

$$
\begin{aligned}
& \text { gradien }(m) \quad=\frac{E_{\alpha s}-E_{206,2128}}{t_{s 0}-t_{0,32}} \\
& 2.366,1350=\frac{460-206,2128}{t_{\text {ร० }}-0,16} \\
& 2.366,1350\left(t_{\text {So }}-0,16\right)=460-206,2128 \\
& t_{\mathrm{SO}}-0,16=\frac{253,7872}{2.366,1350} \\
& t_{\text {so }}-0,16=0,1073 \\
& t_{\text {รO }}=0,1073+0,16 \\
& t_{\text {SO }}=0,2673 \mu \mathrm{s}
\end{aligned}
$$

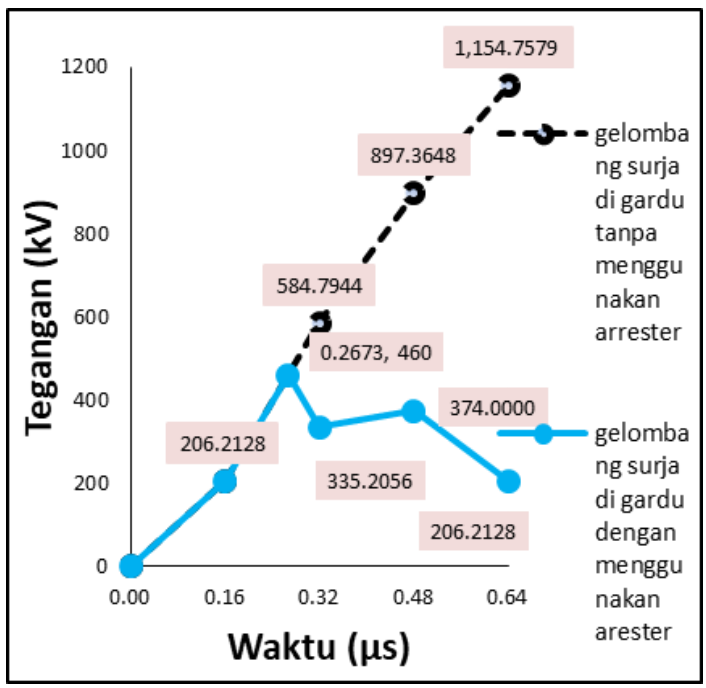

Gambar 7. Tegangan pada arrester saat gelombang surja sampai ke gardu induk. 
Tegangan pada arrester dan waktu untuk mencapainya dapat diperoleh dari Gambar 6 dan besar tegangan pada arrester dapat dilihat pada Gambar 7

\section{Menghitung nilai tegangan akhir pada transformator.}

$$
\begin{aligned}
& \text { Untuk t } \\
& =0 \mu \mathrm{s} \\
& E_{\text {otrafo }} \\
& =0,0000 \mathrm{kV} \\
& \text { Untuk } t \\
& =0,16 \mu \mathrm{s} \\
& E_{1 \text { trafo }} \\
& =0,0000 \mathrm{kV} \\
& =0,32 \mu s \\
& \mathrm{E}_{2 \text { trafo }}=\mathrm{E}_{1 \text { trafo }}+\mathrm{e}_{1 \text { pantul }}+\mathrm{e}_{2 \text { pantul }} \\
& =0+206,2128+172,3687 \\
& =378,5816 \mathrm{kV} \\
& =0,48 \mu s \\
& E_{\text {atrafo }}=E_{2 \text { trafo }}+e_{2 \text { pantul }}+e_{\text {a pantul }} \\
& E_{\text {a trafo }}=378,5816+172,3687+140,2016 \\
& =691.1519 \mathrm{kV} \\
& \text { Untuk t } \quad=0,64 \mu \mathrm{s} \\
& \mathrm{E}_{4 \text { trafo }}=\mathrm{E}_{\text {atrafo }}+\mathrm{e}_{2 \text { pantul }}+\mathrm{e}_{4 \text { pantul }} \\
& =691.1519+140,2016+117,2819 \\
& =948,5450 \mathrm{kV} \\
& \text { Untuk t } \quad=0,80 \mu \mathrm{s} \\
& E_{5 \text { trafo }}=E_{4 \text { trafo }}+e_{4 \text { pantul }}+e_{5} \text { pantul } \\
& =948,5450+117,2819+95,3214 \\
& =1.161,1483 \mathrm{kV}
\end{aligned}
$$

Tegangan pada transformator dapat dicari untuk rentang waktu selanjutnya dan hasilnya dapat dilihat pada tabel 4.

Tabel 4 Tegangan pada transformator.

\begin{tabular}{|c|c|c|}
\hline No & $\begin{array}{c}\text { Waktu } \\
(\mu \mathrm{s})\end{array}$ & $\begin{array}{c}\text { Tegangan } \\
\text { padaTransformator } \\
(\mathrm{kV})\end{array}$ \\
\hline 1 & 0.00 & 0 \\
\hline 2 & 0,16 & 0 \\
\hline 3 & 0,32 & 378,5816 \\
\hline 4 & 0,48 & 691,1519 \\
\hline 5 & 0,64 & 948,5450 \\
\hline 6 & 0,80 & $1.161,1483$ \\
\hline 7 & 0,96 & $1.336,1467$ \\
\hline
\end{tabular}

Menghitung tegangan akhir yang sampai di transformator yaitu:

$$
\begin{array}{cl}
\text { gradien (m) } & =\frac{E_{\text {trafo }}-E_{\text {a7g, g545 }}}{t_{\text {trafo }}-t_{0,92}} \\
1.953,5643 & =\frac{E_{\text {trafo }}-378,5816}{0,4273-0,32} \\
E_{\text {trafo }}-378,5816 & =1.953,5643(0,1073)
\end{array}
$$

$$
\begin{aligned}
\mathrm{E}_{\text {trafo }}-378,5816 & =209,5356 \\
\mathrm{E}_{\text {trafo }} & =209,5356+378,5816 \\
& =588,1172 \mathrm{kV}
\end{aligned}
$$

Perhitungan tegangan akhir pada transformator digunakan sebagai dasar untuk menyusun grafik dan dapat dilihat pada gambar 8 .

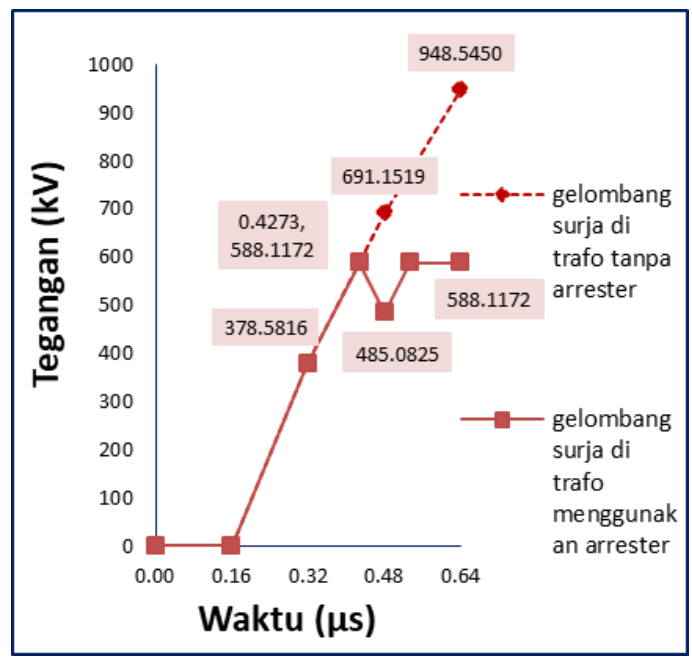

Gambar 8. Tegangan pada transformator saat gelombang surja sampai ke gardu induk.

Berdasarkan gambar 7 dan gambar 8 , maka dapat dilihat perbandingan tegangan pada arrester dan tegangan pada transformator pada gambar 9 .

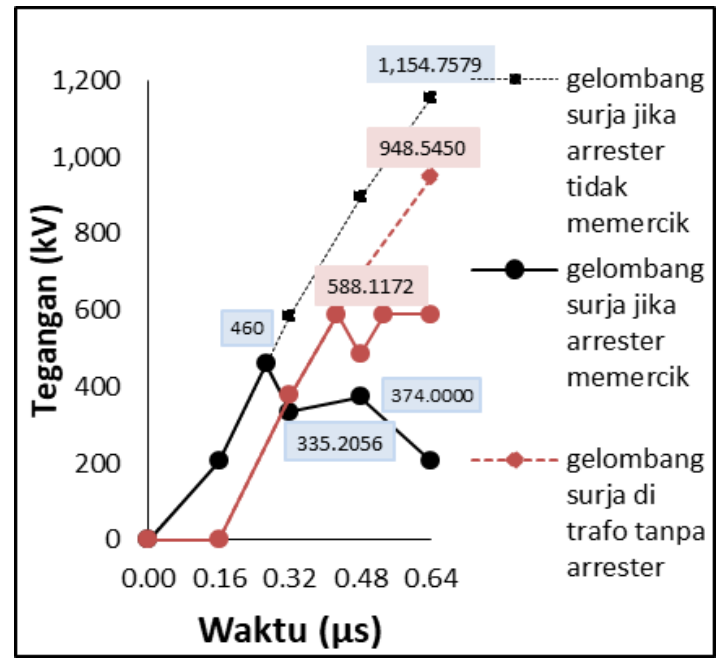

Gambar 9. Perbandingan tegangan pada arrester dan tegangan pada transformator saat gelombang surja sampai ke gardu induk.

Berdasarkan analisis arus pelepasan arrester, jarak pemasangan arrester dan transformator, dan tegangan pada transformator, maka koordinasi isolasi antara arrester dan transformator yang ada di Gardu 
Induk Kuta memenuhi syarat koordinasi isolasi yang baik.

\section{KESIMPULAN}

Kesimpulan berdasarkan hasil dan pembahasan adalah:

1. Saluran transmisi $150 \mathrm{kV}$ Sengkol-Kuta menggunakan saluran ganda dengan menara tipe AA4 konfigurasi vertikal dan dengan hari guruh sebesar 121, diperoleh besar lightning performancenya adalah 1,2948 gangguan per $100 \mathrm{~km}$ per tahun yang berkualifikasi "Pentanahan bagus; perisai yang cukup" sehingga tidak perlu dilakukan perbaikan.

2. Berdasarkan hasil perhitungan, koordinasi isolasi di gardu induk Kuta terhadap tegangan lebih akibat sambaran petir pada saluran transmisi $150 \mathrm{kV}$ dapat dikatakan baik karena :

a. Nilai arus pelepasan arrester yaitu 3,9180 kA. Sedangkan arus pelepasan nominal arrester sebesar $10 \mathrm{kA}$. Hal ini berarti bahwa arus pelepasan arrester lebih kecil 6,0820 kA dari arus pelepasan nominal.

b. Nilai jarak maksimum pemasangan arrester dan transformator sebesar 57 meter. Sedangkan jarak pemasangan arrester dan transformator yang ada dilapangan sebesar 48 meter. Hal ini berarti bahwa jarak pemasangan arrester dan transformator yang ada dilapangan lebih kecil 6 meter dari jarak maksimum arrester dan transformator dari hasil perhitungan.

c. Nilai tegangan akhir yang sampai di transformator sebesar 588,2783 kV. Sedangkan Tingkat Isolasi Dasar (TID) transformator yang digunakan sebesar $650 \mathrm{kV}$. Hal ini berarti bahwa tegangan tertinggi pada transformator lebih kecil $61,7217 \mathrm{kV}$ dari Tingkat Isolasi Dasar (TID) transformator yang digunakan. Sehingga bisa dikatakan bahwa arrester masih mampu menahan tegangan lebih petir yang datang dari saluran transmisi.

\section{DAFTAR PUSTAKA}

Hutauruk, T.S., 1991, Gelombang Berjalan dan Proteksi Surja, Erlangga, Jakarta.

Team O \& M Transmisi dan Gardu Induk PLN Pembangkit Jawa Barat dan Jakarta Raya., 1981, Buku Petunjuk Operasi dan Memelihara Peralatan, No. O \& M: 03/BTG/KJJ/1981, Jakarta: PLN.
Zoro, Reynaldo., 2011, Proteksi Sistem Tenaga: Proteksi terhadap Tegangan Lebih pada Sistem Tenaga Listrik, Diktat Program Studi Teknik Elektro, ITB,Bandung. 